\title{
Serum trace metals in Pre-Eclamptic Nigerians
}

\author{
Ikechukwu Chidiebere Ikaraoha', Nkeiruka Chigaekwu Mbadiwe², John Ibhagbemien Anetor ${ }^{3}$, \\ Isreal Agware Ojareva ${ }^{4}$
}

${ }^{1}$ Chemical Pathology Unit, Department of Medical Laboratory Science, Faculty of Health Science, Imo State University, Owerri, Imo State, Nigeria, ${ }^{2}$ Department of Medicine, University of Nigeria Teaching Hospital, Enugu, Nigeria, ${ }^{3}$ Department of Chemical Pathology, College of Medicine, University of Ibadan, Ibadan, Nigeria, ${ }^{4}$ Department of Chemical Pathology, School of Clinical Medicine, Igbinedion University, Okada, Edo State, Nigeria

Background: The role of trace metals in Pathogenesis of Pre-eclampsia has received insufficient attention in Nigeria. Materials and Methods: We examined the effect of serum levels of some trace metals; selenium (Se), zinc ( $\mathrm{Zn})$, copper ( $\mathrm{Cu})$, cobalt (Co), and manganese $(\mathrm{Mn})$ in the development of pre-eclampsia in Nigeria. Blood samples were collected from 59 pre-eclamptic, 150 normal pregnant and 122 non pregnant women. Serum Se, Zn, Cu, Co and Mn were determined by AAS. Results: Result shows significantly lower serum $\mathrm{Se}, \mathrm{Zn}, \mathrm{Cu}$, $\mathrm{Cu}$ : $\mathrm{Zn}$ ratio, Co and $\mathrm{Mn}$ in pre-eclamptics compared to normal pregnant women $(\mathrm{p}<0.001)$. Comparison of normal pregnant women and controls showed non significant difference in the zinc level $(P>0.05)$, significantly lower levels of serum Se, Co, Mn $(p<0.00011$, $p=0.0022, p<0.0001$ respectively) and significantly raised copper level $(p<0.001)$ in normal pregnant women compared to controls. Serum Se, Zn, Co and Mn were significantly lower $(p<0.001)$ while serum copper and $\mathrm{Cu}$ : $\mathrm{Zn}$ ratio were significantly higher $(p<0.001)$ in pregnant women compared to controls. ANOVA shows significant progressive decreases in serum Se, $\mathrm{Zn}$ Co and $\mathrm{Mn}$, from controls to normal pregnant women and pre-eclamptics $(p<0.0001)$. Conclusion: Decreases in serum level of $\mathrm{Se}, \mathrm{Zn}, \mathrm{Cu}, \mathrm{Cu}: \mathrm{Zn}$ ratio, Co and $\mathrm{Mn}$ may play important role in the pathogenesis of pre-eclampsia.

Key words: Trace metals, pregnant women, Pre-eclampsia, Nigeria

\section{INTRODUCTION}

Trace metals are a group of inorganic elements which are present in the body in minute quantities usually in micrograms or picograms per gram wet tissue and whose recommended daily allowance (RDA) is less than $5 \mathrm{mg}$. ${ }^{1}$ Trace metals have important influence on the health of man and of pregnant women and the growing fetus in particular. ${ }^{2}$ However their possible antioxidant function and contribution in determination of pregnancy disorders where oxidative stress is high has received insufficient attention particular in this environment Nigeria. Preeclampsia is one of such pregnancy disorders, and is a major cause of maternal and perinatal mortality and morbidity. ${ }^{3}$ Pre-eclampsia is associated with high incidence of obstetrics interventions such as induction of labour, or caesarean section either in fetal or maternal interest or both. ${ }^{4}$ Despite several studies on pre-eclampsia, its etiology has not yet been fully elucidated. A previous report shows that approximately 37,000 Nigerian women die annually because of pre-eclampsia related complication, ${ }^{5}$ yet the exact mechanism of development of the disorder is not known. Several reports show that various elements might play an important role in etiology of pre-eclampsia, ${ }^{6,7}$ but it has not been adequately examined in this environment. There are still many gaps that have not been elucidated, owing to the variations of pregnancy influencing factors which may vary from environment to environment. This study has the potential of contributing to the knowledge of the role of trace metals in pre-eclampsia in this part of the world. It therefore appears instructive to properly investigate the possible relationship of some trace metals level in maternal blood, and to correlate the findings with development of pre-eclampsia in Southern-Nigerian women. This study was conducted to examine this possibility and implications for maternal and fetal health. 


\section{MATERIALS AND METHODS}

\section{Study population}

A cohort of pregnant women who commenced prenatal care at the antenatal clinic and wards of the Irrua Specialist Teaching Hospital Irrua, Edo state, southern part of Nigeria were enrolled. Each participant signed an Informed Consent Form after the procedure and implications were explained to the subject in English Language or Special English. Research and Ethics Committee of Irrua Specialist Teaching Hospital Irrua, Edo state, granted ethical approval for this study.

We examined 209 pregnant women within the age range of 20 to 35 years. The pregnant women consist of 150 normal pregnant women and 59 women with pre-eclampsia. They were age matched with 122 non pregnant women (the control group), who were selected after screening for pregnancy. The exclusion criterion was history of any chronic disease.

Using a standard mercury sphygmomanometer (Accoson, Essex, UK), maternal blood pressure during earlier routine monthly visits and later weekly visits as the pregnancy advances was measured with the subject in supine position. The subjects were also tested for presence of protein and glucose in their urine on each monthly visit, using Medi-Test Combi 2 strips (MachereyNagel, Duren, Germany.). Those with glycosuria were excluded from the study. Women were classified as having Pre-eclampsia based on Systolic Blood Pressure (SBP) $\geq 140 \mathrm{mmHg}$ and/or Diastolic Blood Pressure (DBP) $\geq 90 \mathrm{mmHg}$ and proteinuria, ${ }^{8}$ measured during at least two visits after the 22 nd week of gestation, such that the elevated measures could have occurred at any point after 22 weeks, hence no diagnosis of Pre-eclampsia was made before 24 weeks. An average of the last two measurements at different periods before delivery was used to determine the values for Systolic Blood pressure (SBP) and Diastolic Blood Pressure (DBP) assigned to each subject. The gestational age was determined from the last menstrual period (LMP). But if pre-eclampsia develops, they were retained in the clinic for closer monitoring and their B.P measured at least twice daily. Medication (diaxapam $10 \mathrm{mg}$ intravenous injection) was given and if there was no improvement within 48 hours, the patient is booked for assisted delivery.

\section{Blood sample collection}

Seven milliliters of venous blood collected from each participant at delivery was dispensed into plain container, allowed to clot and the serum was separated, stored frozen and analyzed within 4 days for trace metals; Se, $\mathrm{Zn}, \mathrm{Cu}$, Co and Mn.

\section{Methods}

Atomic absorption spectrophotometer model-200A, (Buck Scientific, East Norwalk, UK.) was employed for serum Se, $\mathrm{Zn}, \mathrm{Cu}, \mathrm{Co}$, and $\mathrm{Mn}$ determination as previously described by Welz.' The principle is based on the dissociation of the element (from the flame) from its chemical bonds. This is then placed in unexcited or ground state (neutral atom). Thus, the neutral atom is at a low energy level in which it is capable of absorbing radiation at a very narrow bandwidth corresponding to its own line spectrum. The amount of radiant energy absorbed is proportional to the concentration of trace elements present in the serum. The digested samples were analyzed in duplicates by the instrument, and the average reading taken. Repeated analyses of standard solutions confirmed the method's precision. The $\mathrm{Cu}$ : $\mathrm{Zn}$ ratio was calculated by dividing value of the concentration of $\mathrm{Cu}$ by that of $\mathrm{Zn}$.

\section{Statistical analysis}

All data generated from this study were subjected to statistical analysis, using SPSS 16.0 software for Windows (SPSS, Chicago, IL, USA). The mean, standard deviations, student's t- test and Pearson Correlation were computed. Results were expressed as Mean \pm SD. The $5 \%(\mathrm{P}<0.05)$ level of significance was adopted to infer significant change.

\section{RESULTS}

Table 1; There was significant lower serum Se, Zn, Co and Mn levels in Pregnant women compared to non-pregnant women (controls) $(\mathrm{p}<0.001$ in each case), while serum $\mathrm{Cu}$ level and $\mathrm{Cu}$ : $\mathrm{Zn}$ ratio were significantly higher in pregnant women than in non- pregnant women $(p<0.001)$. SBP and DBP were significantly increased in pregnant women compared to the non pregnant women (controls) $(\mathrm{p}<0.001$ and $\mathrm{p}<0.05$ respectively).

Table 2 shows significantly lower serum Se, Zn, Cu, Cu: Zn ratio, $\mathrm{Co}$, and $\mathrm{Mn}$ levels in women with pre-eclampsia than in normal pregnant women $(\mathrm{p}<0.001$ in each case).

Table 3; Serum Se, Co and Mn were statistically lower in normal pregnant women than in non-pregnant women (controls) $(p<0.0001, p=0.0022$, and $p<0.0001$ respectively). While serum $\mathrm{Cu}, \mathrm{Cu}$ : $\mathrm{Zn}$ ratio, and $\mathrm{SBP}$ were significantly higher in normal pregnant women than in non-pregnant women $(\mathrm{p}<0.001, \mathrm{p}<0.001$, and $\mathrm{p}<0.01$ respectively). SBP in normal pregnant women compared to the non pregnant women $(\mathrm{p}>0.05)$,

Table 4; ANOVA shows significant progressive decreases in serum Se, Zn, Co and Mn levels ( $\mathrm{p}<0.001$ in each case) and significant progressive increases in SBP and DBP 


\begin{tabular}{|c|c|c|c|c|}
\hline $\begin{array}{l}\text { Variables } \\
\text { (mean } \pm S D)\end{array}$ & $\begin{array}{l}\text { Pregnant } \\
\text { women } \\
(n=209)\end{array}$ & $\begin{array}{c}\text { Non-pregnant } \\
\text { women } \\
\text { (controls) } \\
(n=122)\end{array}$ & t-value & $p$-value \\
\hline $\begin{array}{l}\mathrm{Se}(\mu \mathrm{g} / \mathrm{dl}) \\
\text { Lower } 95 \% \mathrm{Cl} \\
\text { Upper } 95 \% \mathrm{Cl}\end{array}$ & $\begin{array}{c}18.3 \pm 8.4 \\
17.1 \\
19.4\end{array}$ & $\begin{array}{c}27.7 \pm 7.2 \\
26.4 \\
29.0\end{array}$ & 10.243 & 0.0001 \\
\hline $\begin{array}{l}\mathrm{Zn}(\mu \mathrm{g} / \mathrm{dl}) \\
\text { Lower } 95 \% \mathrm{Cl} \\
\text { Upper } 95 \% \mathrm{Cl}\end{array}$ & $\begin{array}{c}62.0 \pm 14.1 \\
60.1 \\
63.9\end{array}$ & $\begin{array}{c}95.8 \pm 17.3 \\
92.7 \\
98.9\end{array}$ & 9.6205 & 0.001 \\
\hline $\begin{array}{l}\text { Cu }(\mu \mathrm{g} / \mathrm{dl}) \\
\text { Lower } 95 \% \mathrm{Cl} \\
\text { Upper } 95 \% \mathrm{Cl}\end{array}$ & $\begin{array}{c}141.0 \pm 42.2 \\
135.3 \\
146.8\end{array}$ & $\begin{array}{c}106.7 \pm 16.5 \\
103.8 \\
109.7\end{array}$ & 5.3201 & 0.001 \\
\hline $\begin{array}{l}\text { Cu:Zn ratio } \\
\text { Lower } 95 \% \mathrm{Cl} \\
\text { Upper } 95 \% \mathrm{Cl}\end{array}$ & $\begin{array}{c}2.26 \pm 0.43 \\
2.20 \\
2.32\end{array}$ & $\begin{array}{c}1.13 \pm 0.18 \\
1.09 \\
1.16\end{array}$ & 8.7656 & 0.001 \\
\hline $\begin{array}{l}\text { Co }(\mu \mathrm{g} / \mathrm{dl}) \\
\text { Lower } 95 \% \mathrm{Cl} \\
\text { Upper } 95 \% \mathrm{Cl}\end{array}$ & $\begin{array}{c}2.2 \pm 0.8 \\
2.1 \\
2.3\end{array}$ & $\begin{array}{c}2.7 \pm 0.7 \\
2.6 \\
2.9\end{array}$ & 6.202 & 0.0001 \\
\hline $\begin{array}{l}\mathrm{Mn}(\mu \mathrm{g} / \mathrm{dl}) \\
\text { Lower } 95 \% \mathrm{Cl} \\
\text { Upper } 95 \% \mathrm{Cl}\end{array}$ & $\begin{array}{c}0.88 \pm 0.29 \\
0.84 \\
0.91\end{array}$ & $\begin{array}{c}1.16 \pm 0.27 \\
1.10 \\
1.20\end{array}$ & 11.631 & 0.0001 \\
\hline $\begin{array}{l}\text { SBP }(\mathrm{mmHg}) \\
\text { Lower } 95 \% \mathrm{Cl} \\
\text { Upper } 95 \% \mathrm{Cl}\end{array}$ & $\begin{array}{c}131.8 \pm 31.5 \\
127.5 \\
136.1\end{array}$ & $\begin{array}{c}111.7 \pm 9.9 \\
110.4 \\
114.4\end{array}$ & 6.820 & 0.0001 \\
\hline $\begin{array}{l}\text { DBP }(\mathrm{mmHg}) \\
\text { Lower } 95 \% \mathrm{Cl} \\
\text { Upper } 95 \% \mathrm{Cl}\end{array}$ & $\begin{array}{c}84.0 \pm 20.6 \\
81.2 \\
86.8\end{array}$ & $\begin{array}{c}67.4 \pm 4.3 \\
66.5 \\
69.2\end{array}$ & 8.624 & 0.0001 \\
\hline
\end{tabular}

\begin{tabular}{|c|c|c|c|c|}
\hline $\begin{array}{l}\text { Variables } \\
\text { (mean } \pm S D)\end{array}$ & $\begin{array}{l}\text { Women with } \\
\text { pre-eclampsia } \\
(n=59)\end{array}$ & $\begin{array}{c}\text { Normal } \\
\text { pregnant } \\
\text { women } \\
(n=150)\end{array}$ & t-value & p-value \\
\hline $\begin{array}{l}\text { Se }(\mu \mathrm{g} / \mathrm{dl}) \\
\text { Lower } 95 \% \mathrm{Cl} \\
\text { Upper } 95 \% \mathrm{Cl}\end{array}$ & $\begin{array}{c}8.8 \pm 3.0 \\
8.0 \\
9.6\end{array}$ & $\begin{array}{c}22.0 \pm 7.0 \\
20.8 \\
23.1\end{array}$ & 13.881 & 0.0001 \\
\hline $\begin{array}{l}\mathrm{Zn}(\mu \mathrm{g} / \mathrm{dl}) \\
\text { Lower } 95 \% \mathrm{Cl} \\
\text { Upper } 95 \% \mathrm{Cl}\end{array}$ & $\begin{array}{c}45.8 \pm 9.7 \\
42.9 \\
47.7\end{array}$ & $\begin{array}{c}68.2 \pm 10.1 \\
66.8 \\
70.0\end{array}$ & 8.3626 & 0.001 \\
\hline $\begin{array}{l}\mathrm{Cu}((\mu \mathrm{g} / \mathrm{dl}) \\
\text { Lower } 95 \% \mathrm{Cl} \\
\text { Upper } 95 \% \mathrm{Cl}\end{array}$ & $\begin{array}{c}86.7 \pm 16.5 \\
82.2 \\
90.5\end{array}$ & $\begin{array}{c}162.4 \pm 27.4 \\
157.6 \\
166.5\end{array}$ & 7.9386 & 0.001 \\
\hline $\begin{array}{l}\text { Cu:Zn ratio } \\
\text { Lower } 95 \% \mathrm{Cl} \\
\text { Upper } 95 \% \mathrm{Cl}\end{array}$ & $\begin{array}{c}1.93 \pm 0.36 \\
1.83 \\
2.02\end{array}$ & $\begin{array}{c}2.39 \pm 0.38 \\
2.33 \\
2.45\end{array}$ & 7.8564 & 0.001 \\
\hline $\begin{array}{l}\text { Co }(\mu \mathrm{g} / \mathrm{dl}) \\
\text { Lower } 95 \% \mathrm{Cl} \\
\text { Upper } 95 \% \mathrm{Cl}\end{array}$ & $\begin{array}{c}1.5 \pm 0.6 \\
1.3 \\
1.6\end{array}$ & $\begin{array}{c}2.5 \pm 0.7 \\
2.3 \\
2.6\end{array}$ & 9.295 & 0.0001 \\
\hline $\begin{array}{l}\mathrm{Mn}(\mu \mathrm{g} / \mathrm{dl}) \\
\text { Lower } 95 \% \mathrm{Cl} \\
\text { Upper } 95 \% \mathrm{Cl}\end{array}$ & $\begin{array}{c}0.58 \pm 0.22 \\
0.51 \\
0.63\end{array}$ & $\begin{array}{c}0.99 \pm 0.23 \\
0.95 \\
1.03\end{array}$ & 11.808 & 0.0001 \\
\hline $\begin{array}{l}\text { SBP }(\mathrm{mmHg}) \\
\text { Lower } 95 \% \mathrm{Cl} \\
\text { Upper } 95 \% \mathrm{Cl}\end{array}$ & $\begin{array}{c}175.2 \pm 20.9 \\
169.2 \\
180.7\end{array}$ & $\begin{array}{c}114.6 \pm 13.1 \\
110.0 \\
116.2\end{array}$ & 25.068 & 0.0001 \\
\hline $\begin{array}{l}\text { DBP }(\mathrm{mmHg}) \\
\text { Lower } 95 \% \mathrm{Cl} \\
\text { Upper } 95 \% \mathrm{Cl}\end{array}$ & $\begin{array}{c}110.6 \pm 15.8 \\
105.8 \\
114.4\end{array}$ & $\begin{array}{c}73.3 \pm 9.8 \\
69.9 \\
74.7\end{array}$ & 20.564 & 0.0001 \\
\hline
\end{tabular}

$(\mathrm{p}<0.001$ respectively) from controls to normal pregnancy and to pre-eclampsia.

\section{DISCUSSION}

The search for understanding of pre-eclampsia and its prevention continues. The mechanism involved in the pathogenesis of the disorder remains uncertain. Selenium, zinc, copper, cobalt and manganese are essential trace metals, and are required for maintenance of normal health in human populations. ${ }^{1,10}$ The observed decreases in serum, $\mathrm{Se}, \mathrm{Zn}, \mathrm{Co}$, and $\mathrm{Mn}$ in pregnant women compared to controls may be as a result of increase in body requirement during pregnancy to meet the mother and baby's need. Also the significant lower serum Se, Co and Mn levels in normal pregnant women compared to controls in this study buttresses that there is primary decrease due to pregnancy. It has been previously reported that whole blood and plasma levels of selenium are lower in pregnant women when compared with non-pregnant women ${ }^{11}$ and decrease as gestation proceeds. ${ }^{12}$

However it seems that these essential trace metals are further decreased in pre-eclampsia. This study shows significant lower serum Se, $\mathrm{Zn}, \mathrm{Cu}$, Co and Mn levels in women with pre-clampsia than in normal pregnant women. It is likely that the decreases in the antioxidant trace metals; selenium, zinc, copper, cobalt and manganese levels may have contributed to the development of preeclampsia in the population of study in this environment. This is buttressed by the observed significant progressive decreases in serum Se, Co and Mn levels from controls to normal pregnancy and to pre-eclampsia as shown by ANOVA in this study. This is consistent with the reports of other investigators from Turkey; a Caucasian population, that there was lower serum manganese ${ }^{13}$ and selenium ${ }^{14}$ levels in pre-eclampsia than in normal pregnancy and non pregnant controls. The findings from this present study from Southern Nigeria are also consistent with a previous report from Osogho in western part of Nigeria. ${ }^{15}$ However there are no previous reports on cobalt in pre-eclampsia.

The mechanism of development of pre-eclampsia is likely to involve increase in oxidative stress. Oxidative stress is defined as an imbalance between the cellular generations of reactive oxygen species (ROS) and the capacity of antioxidants to prevent this phenomenon. High burden of reactive oxygen species (ROS), such as superoxide (O2-) and hydrogen peroxide $\left(\mathrm{H}_{2} \mathrm{O}_{2}\right)$ are normally produced in the course of oxygen metabolism and are safely disposed of by the antioxidant defense system. However, a variety of pathophysiological conditions result in heightened 
production of ROS and/or impaired antioxidant capacity, which culminate in oxidative stress. ${ }^{16,17}$

In the presence of oxidative stress, uncontained ROS cause tissue damage and dysfunction by directly attacking

\begin{tabular}{|c|c|c|c|c|}
\hline $\begin{array}{l}\text { Variables } \\
\text { (mean } \pm S D)\end{array}$ & $\begin{array}{l}\text { Normal } \\
\text { pregnant } \\
\text { women } \\
(n=150)\end{array}$ & $\begin{array}{c}\text { Non-pregnant } \\
\text { women } \\
\text { (controls) } \\
(n=122)\end{array}$ & t-value & $p$-value \\
\hline $\begin{array}{l}\text { Se }(\mu \mathrm{g} / \mathrm{dl}) \\
\text { Lower } 95 \% \mathrm{Cl} \\
\text { Upper } 95 \% \mathrm{Cl}\end{array}$ & $\begin{array}{c}22.0 \pm 7.0 \\
20.8 \\
23.1\end{array}$ & $\begin{array}{c}27.7 \pm 7.2 \\
26.4 \\
29.0\end{array}$ & 6.554 & 0.0001 \\
\hline $\begin{array}{l}\text { Zn( } \mu \mathrm{g} / \mathrm{dl}) \\
\text { Lower } 95 \% \mathrm{Cl} \\
\text { Upper } 95 \% \mathrm{Cl}\end{array}$ & $\begin{array}{c}68.2 \pm 10.1 \\
66.5 \\
69.8\end{array}$ & $\begin{array}{c}95.8 \pm 17.3 \\
92.7 \\
98.9\end{array}$ & 1.2892 & $>0.05$ \\
\hline $\begin{array}{l}\mathrm{Cu}(\mu \mathrm{g} / \mathrm{dl}) \\
\text { Lower } 95 \% \mathrm{Cl} \\
\text { Upper } 95 \% \mathrm{Cl}\end{array}$ & $\begin{array}{c}162.4 \pm 27.4 \\
158.0 \\
166.8\end{array}$ & $\begin{array}{c}106.7 \pm 16.5 \\
103.8 \\
109.7\end{array}$ & 5.6721 & 0.001 \\
\hline $\begin{array}{l}\text { Cu:Zn ratio } \\
\text { Lower } 95 \% \mathrm{Cl} \\
\text { Upper } 95 \% \mathrm{Cl}\end{array}$ & $\begin{array}{c}2.39 \pm 0.38 \\
2.33 \\
2.45\end{array}$ & $\begin{array}{c}1.13 \pm 0.18 \\
1.09 \\
1.16\end{array}$ & 6.9983 & 0.001 \\
\hline $\begin{array}{l}\text { Co }(\mu \mathrm{g} / \mathrm{dl}) \\
\text { Lower } 95 \% \mathrm{Cl} \\
\text { Upper } 95 \% \mathrm{Cl}\end{array}$ & $\begin{array}{c}2.5 \pm 0.7 \\
2.3 \\
2.6\end{array}$ & $\begin{array}{c}2.7 \pm 0.7 \\
2.6 \\
2.9\end{array}$ & 3.096 & 0.0022 \\
\hline $\begin{array}{l}\text { Mn }(\mu \mathrm{g} / \mathrm{dl}) \\
\text { Lower } 95 \% \mathrm{Cl} \\
\text { Upper } 95 \% \mathrm{Cl}\end{array}$ & $\begin{array}{c}0.99 \pm 0.23 \\
0.95 \\
1.03\end{array}$ & $\begin{array}{c}1.16 \pm 0.27 \\
1.10 \\
1.20\end{array}$ & 8.870 & 0.0001 \\
\hline $\begin{array}{l}\text { SBP }(\mathrm{mmHg}) \\
\text { Lower } 95 \% \mathrm{Cl} \\
\text { Upper } 95 \% \mathrm{Cl}\end{array}$ & $\begin{array}{c}114.6 \pm 13.1 \\
112.4 \\
116.7\end{array}$ & $\begin{array}{c}111.7 \pm 9.9 \\
109.8 \\
113.3\end{array}$ & 0.1109 & $>0.05$ \\
\hline $\begin{array}{l}\text { DBP }(\mathrm{mmHg}) \\
\text { Lower } 95 \% \mathrm{Cl} \\
\text { Upper } 95 \% \mathrm{Cl}\end{array}$ & $\begin{array}{c}73.3 \pm 9.8 \\
70.5 \\
74.4\end{array}$ & $\begin{array}{c}67.4 \pm 4.3 \\
66.2 \\
68.7\end{array}$ & 5.600 & 0.0001 \\
\hline
\end{tabular}

and denaturing functional and structural molecules and by activating redox-sensitive transcription factors and signal transduction pathways, thus playing a critical part in the pathogenesis of many acute and chronic illnesses, including hypertension. ${ }^{16,18}$

Selenium; an essential trace metal (micronutrient) is an essential component of theantioxidant selenoproteins, including glutathione peroxidases. These remove the products of peroxidation by hydroperoxidesand oxidized lipoprotein $s^{19}$ and so limit adverse effects of ROS onthe endothelium. ${ }^{20}$ Furthermore, the expression and activity of important anti-oxidant proteins are decreased in placental tissues from pre-eclamptic mothers, resulting in an imbalance between pro-oxidants and anti-oxidants leading to oxidative stress. Two of these anti-oxidant proteins are glutathione peroxidase and thioredoxin reductase, enzymes that have selenocysteine within their active site and are selenium-dependent for activity. ${ }^{21}$ Besides, Manganese is a component of the antioxidant enzyme; manganese superoxide dismutase (MnSOD), and is the principal antioxidant enzyme of the mitochondria. It has been reported that MnSOD deficiency enhanced 12-O-tetradecanoylphorbol-13-acetate (TPA)-induced oxidative stress in mice. ${ }^{13}$

Therefore, it seems that as there is increase in oxidative stress, selenium and manganese get involved in the antioxidant mechanism and is reduced in the process, thus explaining the decrease in selenium and manganese levels in women with pre-eclampsia compared to the normal pregnant women as observed in the present study.

\begin{tabular}{|c|c|c|c|c|c|}
\hline $\begin{array}{l}\text { Variables } \\
\text { (mean } \pm S D)\end{array}$ & $\begin{array}{l}\text { Women with } \\
\text { pre-eclampsia } \\
(n=59)\end{array}$ & $\begin{array}{l}\text { Normal pregnant } \\
\text { women } \\
(n=150)\end{array}$ & $\begin{array}{c}\text { Non-pregnant } \\
\text { women (controls) } \\
(n=122)\end{array}$ & F-value & p-value \\
\hline $\operatorname{Se}(\mu \mathrm{g} / \mathrm{dl})$ & $8.8 \pm 3.0$ & $22.0 \pm 7.0$ & $27.7 \pm 7.2$ & 160.26 & $<0.0001$ \\
\hline Lower $95 \% \mathrm{Cl}$ & 8.0 & 20.8 & & & \\
\hline Upper $95 \% \mathrm{Cl}$ & 9.6 & 23.1 & & & \\
\hline $\mathrm{Zn}(\mu \mathrm{g} / \mathrm{dl})$ & $45.8 \pm 9.7$ & $68.2 \pm 10.1$ & $95.8 \pm 17.3$ & 313.04 & $<0.0001$ \\
\hline Lower 95\% Cl & 42.9 & 66.5 & & & \\
\hline Upper $95 \% \mathrm{Cl}$ & 47.7 & 69.8 & & & \\
\hline $\mathrm{Cu}(\mu \mathrm{g} / \mathrm{dl})$ & $86.7 \pm 16.5$ & $162.4 \pm 27.4$ & $106.7 \pm 16.5$ & 38.604 & $<0.0001$ \\
\hline Lower $95 \% \mathrm{Cl}$ & 82.2 & 158.0 & & & \\
\hline Upper $95 \% \mathrm{Cl}$ & 90.5 & 166.8 & & & \\
\hline Co $(\mu \mathrm{g} / \mathrm{dl})$ & $1.5 \pm 0.6$ & $2.5 \pm 0.7$ & $2.7 \pm 0.7$ & 66.38 & $<0.0001$ \\
\hline Lower $95 \% \mathrm{Cl}$ & 1.3 & 2.3 & & & \\
\hline Upper $95 \% \mathrm{Cl}$ & 1.6 & 2.6 & & & \\
\hline $\mathrm{Mn}(\mu \mathrm{g} / \mathrm{dl})$ & $0.58 \pm 0.22$ & $0.99 \pm 0.23$ & $1.16 \pm 0.27$ & 110.91 & $<0.0001$ \\
\hline Lower $95 \% \mathrm{Cl}$ & 0.51 & 0.95 & & & \\
\hline Upper $95 \% \mathrm{Cl}$ & 0.63 & 1.03 & & & \\
\hline $\mathrm{SBP}(\mathrm{mmHg})$ & $175.2 \pm 20.9$ & $114.6 \pm 13.1$ & $111.7 \pm 9.9$ & 483.15 & $<0.0001$ \\
\hline Lower $95 \% \mathrm{Cl}$ & 169.2 & 112.4 & & & \\
\hline Upper $95 \% \mathrm{Cl}$ & 180.7 & 116.7 & & & \\
\hline $\mathrm{DBP}(\mathrm{mmHg})$ & $110.6 \pm 15.8$ & $73.3 \pm 9.8$ & $67.4 \pm 4.3$ & 377.21 & $<0.0001$ \\
\hline Lower $95 \% \mathrm{Cl}$ & 105.8 & 70.5 & & & \\
\hline Upper $95 \% \mathrm{Cl}$ & 114.4 & 74.4 & & & \\
\hline
\end{tabular}


Decrease in antioxidant trace metals level may cause excessive accumulation of reactive oxygen species (ROS), whichresults in oxidative stress, playing a critical role as a possible mediator of endothelial cell dysfunction, ${ }^{22}$ hypertension, and thus clinical manifestations of preeclampsia. ${ }^{16,23}$ Two previous studies have shown decreases in maternal serum or toenail selenium concentrations in pre-eclamptic patients compared to normal pregnant controls. ${ }^{24,25}$ This is consistent with our present report.

It has been demonstrated that when taken as a supplement, selenium modulates the cellular response to oxidative stress, inducing a faster restoration of the endogenous antioxidative defense system against the production of reactive oxygen species. ${ }^{26}$ However, correlation studies in the present report revealed inverse relationship of selenium with SBP and DBP. This suggests that the lower the selenium level, the higher the oxidative stress as may be manifested through multiple step pathways. ${ }^{16,22,23}$

This study shows significant decreases in serum $\mathrm{Zn}, \mathrm{Cu}$ and $\mathrm{Cu}: \mathrm{Zn}$ ratio levels of women with pre-eclampsia compared to normal pregnant women. Copper and zinc are essential components of the antioxidant enzymes copper-zinc superoxide dismutase ( $\mathrm{Cu}-\mathrm{Zn} \mathrm{SOD})$ which is involved in destruction of free radicals/ROS. ${ }^{27}$ Copper and zinc deficiency might cause insufficiency of $\mathrm{Cu}-\mathrm{Zn}$ $\mathrm{SOD},{ }^{28}$ thereby exposing the women to free radicals/ ROS accumulation and oxidative stress, which may lead to the development of pre-eclampsia. Besides, it has been reported that $\mathrm{Zn}$ deficiency can increase the susceptibility of neurons to oxidative tress. ${ }^{29}$

The potent vasodilator, nitric oxide $(\mathrm{NO})$, is critical to normal vascular function and endothelial integrity. Nitric oxide is essential to the normal adaptive vasodilation of pregnancy in animals and women, and decreased NO bioavailability is thought to contributeto the development of pre-eclampsia. ${ }^{30}$ Copper is also very essential for the release of NO from S-nitrosoalbumin (SNO-Alb.) Robin et $\mathrm{al}^{31}$ reported significant elevations in plasma concentrations of SNO-Alb in women with pre-eclampsia; suggesting a deficiency in copper -mediated release of nitrogen oxide (NO)from SNO-Alb. ${ }^{31}$ This corroborates the decreased copper status observed in women with pre-eclampsia as opposed to normal pregnancy in this present study.

Furthermore, in the present study significantly higher serum $\mathrm{Cu}$ level in normal pregnant women compared to non pregnant women (controls)and women with pre-eclampsia was observed. Serum copper level increases from about $80-155 \mathrm{mg} / \mathrm{dl}$ before pregnancy to about $118-302 \mathrm{mg} / \mathrm{dl}$ by the end of the third trimester. The physiologic increase in copper concentration in pregnancy is in part associated with estrogen induction of copper carrying protein (ceruloplasmin). ${ }^{32}$ However this present study show lower serum $\mathrm{Zn}$ level in pregnant women than controls, and also lower $\mathrm{Zn}$ level in pre-eclamptic women than normal pregnant women (table $1 \& 2$ respectively), thus buttresses that $\mathrm{Zn}$ deficiency may be a major factor in the development of pre-eclampsia in this environment. This corroborates previous report from Saudi Arabia that $\mathrm{Cu}$ and $\mathrm{Zn}$ are decreased in Pre-eclampsia, ${ }^{33,34}$ but is conflicting with a report from Iran that serum $\mathrm{Zn}$ in pre-eclamptics had no significant difference with normotensive subjects. ${ }^{35}$ The present study reveals that decreases in some serum trace metals levels may in part contribute to development of pre-eclampsia in this environment. The Implication/Strength of the present study is that this result may be important to other populations with low levels of these trace metals and the overall Nigerian population in the prevention of pre-eclampsia and other trace metals deficiency-related disorders. The present study has limitation; serial serum trace metals in various trimesters were not included.

\section{CONCLUSION}

Decrease in serum selenium, zinc, copper, $\mathrm{Cu}: \mathrm{Zn}$ ratio, cobalt and manganese levels may play a critical role in the pathogenesis of pre-eclampsia in this environment. There may be need for increase in dietary intake of these essential trace metals during pregnancy to prevent pre-eclampsia in this environment.

\section{ACKNOWLEDGMENTS}

The authors are grateful to Mr Oseke M.O of Chemistry Instrumentation Laboratory, federal University of Technology Akure, Nigeria for his technical assistance during trace metals analysis, and all the women who participated in this study, the midwives and Resident Doctors of Obstetrics and Gynecology Department of Irrua Specialist Teaching Hospital, Irrua, Edo State, Nigeria for their assistance during sample collection.

\section{REFERENCES}

1. World Health Organization. Manganese: In Trace elements in human nutrition and health. Geneva: World Health organization 1996;163.

2. Black RE. Micronutrients in Pregnancy. British Journal of Nutrition 2001;85(2):193-197.

3. Sibai B, Dekker G and Kupferminc M. Pre-eclampsia. Lancet 2005;365:785-799.

4. Anglim B, O'Dwyer V, Farah N, Stuart B and Turner MJ. Body mass index and hypertensive disorders of pregnancy. Pregnancy Hypertension 2011;2(1):28-31. 
5. World Health Organization. Coverage of Maternity Care: A Listing of Available Information. 4th ed. Geneva: World Health Organization; 2004. WHO/RHT/MSM/96.28.

6. Vanderlelie J, Venardos K and Perkins AV. Selenium deficiency as a model of experimental pre-eclampsia in rats. Reproduction 2004;128:635-641.

7. Bringman J, Gibbs $C$ and Ahokas R. Differences in serum calcium and magnesium between gravidas with severe pre-eclampsia and normotensive controls. American Journal of Obstetrics and Gynecology 2006;195:148.

8. Zhang J. Partner change, birth interval and risk of pre-eclampsia: A paradoxical triangle. Paediatrics Perinatology Epidemiology 2007;21(1):31-35

9. Welz B. Atomic absorption spectrophotometry [English translation by Christopher Skegg]. 2nd comp. rev. ed. Weinheim, Germany; Deerfield Beach, Fl: VCH;1985;7-8,167-169.

10. Savarino L, Granchi D, Ciapetti G, Cenni E, Ravaglia G Forti $P$, et al. Serum concentrations of zinc and selenium in elderly people: Results in healthy nonagenarians/centenarians. Experimental Gerontology 2001;36:327-339.

11. Mihailovic M, Cvetkovic M, Ljubic A, Kosanovic M, Nedeljkovic S, Jovanovic I, et al. Selenium and malondialdehyde content and glutathione peroxidase activity in maternal and umbilical cord blood and amniotic fluid. Biological Trace Elements Research 2000;73:47-54

12. Zachara BA, Wardak C, Didkowski W, Maciag A and Marchaluk E. Changes in blood selenium and glutathione concentrations and glutathione peroxidase activity in human pregnancy. Gynecology \& Obstetrics Investigation 1993;35:12-17.

13. Zhao Y, Oberley TD, Chaiswing L, Lin SM, Epstein CJ, Huang TT, et al. Manganese Superoxide Dismutase Deficiency Enhances Cell Turnover via Tumor Promoter-induced Alterations in Ap-1 and P53-mediated Pathways in a Skin Cancer Model. Oncogene 2002;21(24):3836-3846.

14. Mistry HD, Wilson V, Ramsay MM, Symonds ME and Pipkin FB. Reduced Selenium Concentrations and Glutathione Peroxidase Activity in Preeclamptic Pregnancies. Hypertension 2008;52:88.

15. Akinloye O, Oyewale OJ and Oguntibejum OO. Evaluation of trace elements in pregnant women with pre-eclampsia. African Journal of Biotechnology 2010;9(32):5196-5202.

16. Cai $\mathrm{H}$ and Harrison DG. Endothelial dysfunction in cardiovascular diseases: The role of oxidant stress. Circulation Research 2000;87:840-844.

17. Vaziri ND and Sica D. Lead-induced HTN: Role of oxidative stress. Current Hypertention Research 2004; 6: 314-320.

18. Vaziri ND, Lin CY, Farmand F and Sindhu RK. Superoxide dismutase, catalase, glutathione peroxidase and NADPH oxidase in lead-induced HTN. Kidney International 2003;63:186-194.

19. Rayman MP. The importance of selenium to human health. Lancet 2000;356:233-241.

20. Oster $\mathrm{O}$ and Prellwitz W. Selenium and cardiovascular disease. Biological Trace Elements Research1990;24:91-103.

21. Vanderlelie J, Venardos $K$ and Perkins AV. Selenium deficiency as a model of experimental pre-eclampsia in rats. Reproduction
2004;128(5):635-641.

22. Brosnan MJ. One step beyond: Glutathione peroxidase and endothelial dysfunction. Hypertension 2008;51:825-826.

23. Shah PK. Mechanisms of plaque vulnerability and rupture. Journal of American College of Cardiology 2003;41:15S-22S.

24. Atamer $Y$, Kocyigit $Y$, Yokus $B$, Atamer $A$ and Erden AC. Lipid peroxidation, antioxidant defense, status of trace metals and leptin levels in preeclampsia. European Journal of Obstetrics \& Gynecology and Reproductive Biology 2005;119:60-66.

25. Rayman MP, Bode P and Redman CW. Low selenium status is associated with the occurrence of the pregnancy disease preeclampsia in women from the United Kingdom. American Journal of Obstetrics \& Gynecology 2003;189:1343-1349.

26. Jozanov-Stankov O, Demajo M, Djujic I and Mandic M. Selenium intake as a modulator responsiveness to oxidative stress. Journal of Environmental Pathology Toxicology \& Oncology 1998; 17:251-225.

27. Chan, S, Gerson B and Subramaniam S. The role of copper, molybdenum, Selenium and zinc in nutrition and health. Clinical \& Laboratory Medicine 1998;18(4):673-685.

28. Acikgoz S, Harma M, Mungan G, Can M and Demirtas S. Comparison of angiotensin-converting enzyme, malonaldehyde, zinc, and copper levels in preeclampsia. Biological Trace Elements Research 2006;113(1):1-8.

29. Aimo Land Oteiza PI. Zinc Deficiency Increases the Susceptibility of Human Neuroblastoma Cells to Lead-Induced Activator Protein-1 Activation. Toxicological Sciences 2006; 1:184-191.

30. Morris NH, Eaton BM and Dekker G. Nitric oxide, the endothelium, pregnancy and pre-eclampsia. Brittish Journal of Obstetrics \& Gynaecolology 1996; 103: 4-15.

31. Robin EG, Vladimir AT, Wan H, Antonio A, Ashi, Gail $\mathrm{H}$, et al. S-Nitrosoalbumin-Mediated Relaxation Is Enhanced by Plasma Ascorbate and Copper. Effects in Pregnancy and Preeclampsia. Hypertension 2005; 45:21.

32. Ziaei S, Ranjkesh F and Faghihzadeh S. Evaluation of 24Hour Urine Copper in Preeclamptic Vs. Normotensive Pregnant and Non-Pregnant Women. International Journal of Fertility \& Sterility (IJFS) 2008;2(1):9-12.

33. Al-Jameil N, Tabassum $\mathrm{H}$, Al-Mayouf $\mathrm{H}$, Aljohar HI, Alenzi ND, Hijazy SM, et al. Analysis of Serum Trace Elements-Copper, Manganese and Zinc in Preeclamptic Pregnant Women by Inductively Coupled Plasma Optical Emission Spectrometry: "A Prospective Case Controlled Study in Riyadh, Saudi Arabia." International Journal of Clinical \& Experimental Pathology 2014; 7.5:1900-1910.

34. Al-JameilN, Tabassum H, Ali MN, Qadeer MA, Khan FA and Al-Rashed R. Correlation between serum trace elements and risk of preeclampsia: A case controlled study in Riyadh, Saudi Arabia. Saudi Journal of Biological Sciences 10.1016/j. slbs.2015.02.009. In Press. Available online 14 February 2015.

35. Vafaei $H$, Dalili $M$ and Hashemi S. A Serum concentration of calcium, magnesium and zinc in normotensive versus preeclampsia pregnant women: A descriptive study in women of Kerman province of Iran. Iranian Journal of Reproductive Medicine 2015;13(1):23-26.

\section{Authors Contribution:}

$\mathbf{I C I}$ - Concept and design of the study, reviewed the literature, data collection, statistically analyzed and interpreted the data, manuscript preparation and critical revision of the manuscript; MNC - Concept of the study, collected data and review of literature and manuscript preparation and helped in correction of manuscript; AJI - Co-supervised the study, conceptualized study, designed the study, collected data, and prepared first draft of manuscript and critical revision of the manuscript; OIAO - Supervision of the study, Concept and design of study, collected data, manuscript preparation and review of study.

Source of Support: We did not receive any grant for this study. Conflict of Interest: None declared. 